eastern Europe, it is not surprising that this special interest is reflected at the very top: the new chairman, Lord Cairns, has a long history in international relations; and in 1993, the former US Secretary of Agriculture and US trade representative, Clayton Yeutter, was added to the board of directors.

Perhaps some of the less worldly staff at Cambridge may also be asking themselves why a company devoted to making money from selling tobacco should have a "commitment to education", and one which, according to the press release, covers more than 450 universities around the world. Surely such a commitment would be an abuse of shareholders' money? Their more experienced colleagues may be able to explain how considerable influence can be gained from sponsoring a university, especially in less-developed countries, where such funding is desperately hard to find. And if any moral scruples crop up in these countries about taking tobacco money, they will be much easier to overcome by mentioning the Sir Patrick Sheehy professorship and the BAT scholarships at the University of Cambridge.

DAVID SIMPSON Nequs Editor

\section{Liggett comes clean}

Although it is far too early to assess the final outcome of Liggett's decision to settle the Castano class action lawsuit and lawsuits by a half dozen US states ${ }^{*}$, it is already clear that it is the most important change in tobacco company policy since the dangers of smoking first became known.

In March, Liggett, a subsidiary of the Brooke Group and manufacturer of Chesterfield, Lark, Eve, and L\&M cigarettes, broke ranks with the rest of the US tobacco industry by offering to reach a multi-million dollar out-ofcourt settlement with tobacco control litigants. Liggett only has about $2 \%$ of the US market, but its decision rocked the tobacco industry and Wall Street alike. It will be the first time any US tobacco manufacturer has paid money to settle such a tobacco liability lawsuit. Liggett's move came as it faced a new type of lawsuit, the Castano class action suit, in which lawyers are seeking compensation on behalf of all present and former smokers not for health damage, but for the costs of their nicotine addiction, including a refund of money spent on cigarettes.

Liggett's proposed deal will settle both this case and also the separateand novel-litigation in which a half dozen US states ${ }^{\star}$ are suing the US tobacco industry for the costs of treating smoking-related diseases under ${ }^{-1}$ public assistance programmes such as Medicaid. In the Castano case the 0 company has signed a provisional agreement with the plaintiffs' lawyers to pay out $5 \%$ of its pre-tax profits up $\underset{\mathrm{S}}{\vec{\rho}}$ to a maximum of US $\$ 50$ million per $\frac{7}{0}$ year for the next 25 years. The money $\frac{C}{\partial}$ will not go to individuals, but to $\overline{\bar{p}}$ programmes aimed at helping people to give up smoking. In the medical $\frac{\Omega}{2}$ costs action, the company is negotiat- $\infty$ ing a deal under which it will pay $\vec{\circ}$ $2-7 \%$ of pre-tax income towards $\overrightarrow{\vec{\omega}}$ smoking-related healthcare costs over ${ }^{\omega}$ the next 24 years, the precise figure to $?$ depend on how many states join the or settlement. There will also be an up-front cash payment.

In addition, Liggett agreed to drop 을 its opposition to some of the proposed Food and Drug Administration $\check{c}$ (FDA) regulations on smoking, and $\bar{\nabla}$ will implement some of the FDA's $\vec{\varphi}$ plans to protect children and $\mathscr{E}$ adolescents, including restrictions on advertising.

Importantly, the settlement terms will apply if Liggett should merge with any other company that has less than $\frac{0}{D}$ $30 \%$ of the US market, which in practice means any except Philip Morris. 을 RJ Reynolds, the second biggest US tobacco manufacturer, would fall into this category; and Mr Bennett LeBow, the US financier who controls Liggett, is trying to take control of RJR Nabisco and to force it to separate its food and tobacco business, a strategy he has been pursuing since last year.

Predictably, reactions to the announcement of the deal were 3 . mixed. President Bill Clinton said it $\delta$ was "the first crack in the stone wall of denial", and used the opportunity to 윽 reiterate his determination to press ahead with FDA regulation of tobacco. FDA commissioner David N Kessler said: "It is encouraging that at least one company recognizes that $N$ there is a real effect on our children by $\omega$ all the advertising and promotion of ${ }^{O}$ the industry." The financial markets were shocked and tobacco company $\stackrel{D}{\rightarrow}$ stocks fell sharply, but only by $5-10 \%$, except for RJR Nabisco, which fell by $15 \%$. Much of the market analysis centred on whether the Liggett settle- $\frac{\mathbb{D}}{\mathbb{Q}}$ ment was merely part of Mr LeBow's strategy to gain control of RJR Nabisco.

Perhaps the most telling reactions were from the other, larger US tobacco companies. Philip Morris was

A half dozen states when the Liggatt settlement was first announced but now more than a dozen.-ED 
predictably furious and was reported to be considering a special mention of Liggett in its next magazine advertisement campaign against youth smoking, aimed at improving its image and fending off FDA regulation. Liggett may be added to the existing enemies PM is trying to discredit, the FDA and product liability plaintiffs' lawyers, which it wants to portray as hypocritical for "wrapping themselves in the youth flag" to further their own agendas.

RJR Nabisco neatly illustrated the wealth-versus-health core of the whole tobacco problem when it stated, apparently oblivious to the ironies involved, that its own management decisions had been responsible compared with those of its stalker, Bennett LeBow. In an advertisement in the Wall Street Fournal, RJR said Mr LeBow had "demonstrated his reckless disregard"-not for health, but for "the long-term interests of RJR Nabisco shareholders". But RJR Nabisco's chief executive told a British newspaper that, speaking hypothetically, the industry might consider settlement of all tobacco liability suits in exchange for a US government guarantee of immunity from tobacco lawsuits.

And that would seem to be the bottom line: what will it cost to settle, to be immune forever? Astronomical though it would be (recent reports from Washington speak of deals requiring industry payments of $\$ 10$ billion per year), perhaps it might still be less than the cost of battling it out indefinitely, especially with the constant stream of whistle-blowers emerging from the woodwork with new evidence of industry deceit. Since August, when a Florida court awarded damages to a lung cancer victim's widow, and President Clinton announced he was backing FDA regulation of tobacco, the immunity issue has come to the fore again, including a draft bill circulating in Congress. Calculations are no doubt being made, involving sums rather larger than would fit on the back of a cigarette pack, to see whether the price of peace is worth it. If so, it would remain to be seen how the eventual change in the industry's behaviour in the USA would affect what it did elsewhere in the world. All this may be idle speculation; and meanwhile, it's business as usual for all but Liggett. As the San Francisco Chronicle put it, "We expect they [the other cigarette manufacturers] will fight like rabid dogs to preserve and enhance their immense profits. But by breaking ranks, Liggett has cracked the tobacco industry's armor and emboldened the antismoking army."-DS

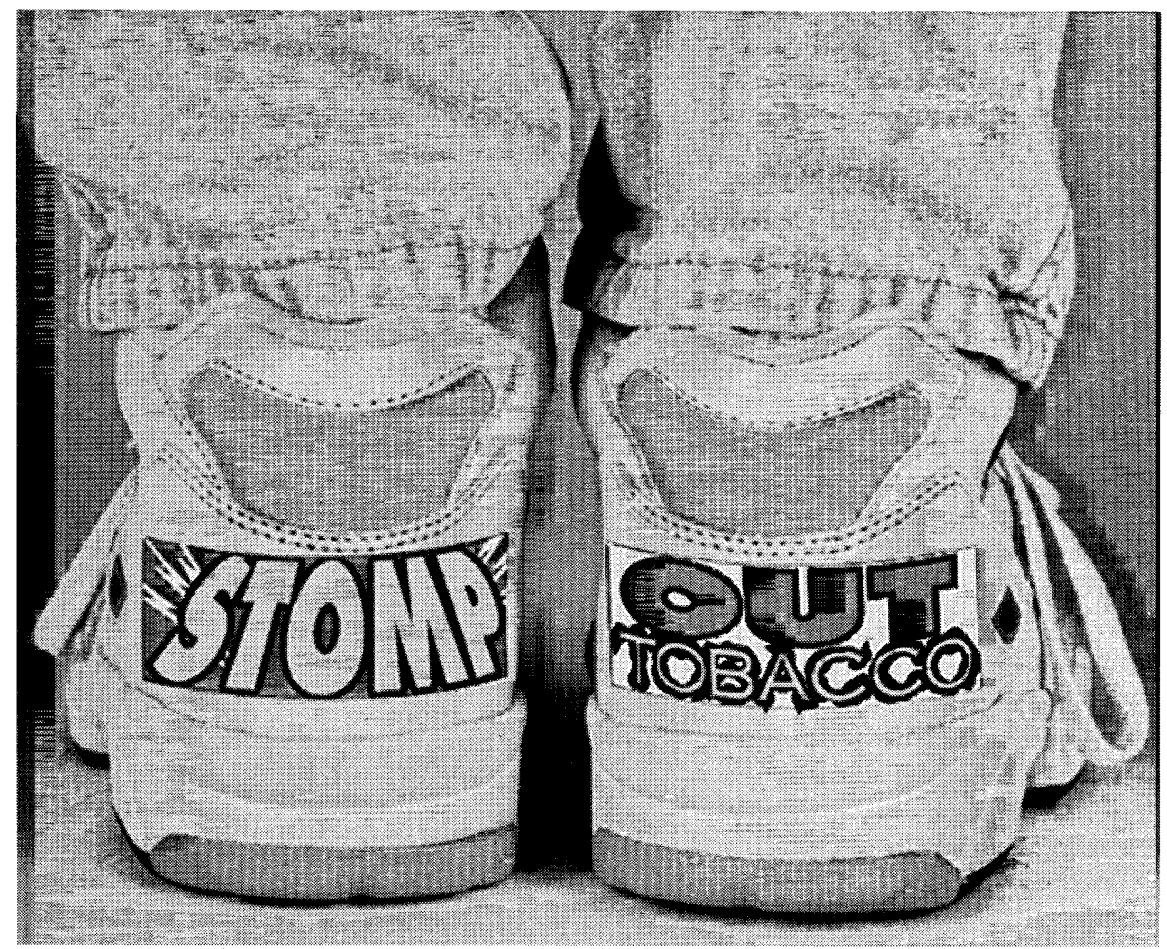

Figure 2 Now it's bumper stickers for shoes- “Grafeeties” stickers promote health messages.

\section{Bumper bundle}

Bumper stickers are nothing if not quintessentially American. For one thing, only the US had such abundantly cheap petroleum to allow cars to be made so huge that their bumpers were mobile billboards just crying out for messages. Becoming respectable, bumper stickers began to be a routine communications medium, especially for up-to-the-minute political commentary. When Senator Barry Goldwater stood for President in 1964, his campaign slogan "In your heart, you know he's right", seen on bumpers and billboards alike, was soon answered by rival bumper stickers reading: "In your guts, you know he's nuts". Years later came evidence that such classics of the genre had earned a place in the great American subconscious. Within hours of Playboy magazine publishing an interview with President Jimmy Carter confessing that he had, on occasion, looked at other women with desire, bumper stickers were spotted in New York commenting: "In his heart, he knows your wife".

Now it's bumper stickers for shoes - well, children's shoes, anyway. Naturally, they are from the US too, not just because they derive from car bumper stickers, but no doubt also because American children seem to have been the first to wear trainers-or sneakers, as they are called in the US-more or less from birth. A range of bright, colourful, child-friendly, trendsetting stickers with health promotion messages is being actively promoted and, according to their makers, already being used by hundreds of US health programmes. Covering not only smoking - your left shoe says "STOMP" and your right shoe continues "OUT TOBACCO"- the "Grafeeties" include stickers on HIV/AIDS, alcohol abuse, and crime and violence prevention as well (figure 2). Of course, to get your heels read-the stickers fit just over the heel block of your trainers-you have to be out in front, but that's where most kids want to be.-DS

Details from EYE-D Unlimited Inc, 1730 Blake Street, Suite 400, Denver, Colorado 80202, USA; tel: +1 303291 1011; fax: +13032911113.

\section{Ad-free brand}

\section{launch}

WD \& HO Wills, BAT's Australian subsidiary, reveals in its 1995 Annual Report that brands can be launched very successfully despite almost total advertising bans. Wills states, "The re-launch of Horizon as Australia's 'Best Value' brand has steadily recouped market share lost in the price war. ... Horizon ended 1995 as the 4th largest brand in Australia which is especially pleasing, considering its launch was undertaken in the restrained advertising environment of the 1990s."

Restrained is something of an understatement. Throughout 1995, 
Australian tobacco companies were only permitted to advertise at the point of sale; with all print, electronic, cinema, sampling, print media, and outdoor advertising having been progressively banned since 1976 .

The tobacco industry often argues to governments that advertising bans will prevent companies from launching new brands. "An advertising ban will not allow us to inform consumers about new innovations in tobacco products," they say, alluding to their concerns to let smokers know about lower yielding brands that might kill them less quickly. Wills' Australian experience with Horizon gives the lie to yet another industry argument against advertising bans.

SIMON CHAPMAN Deputy Editor

\section{Smoke-free medical school}

In April, Shanghai Medical University became the first university in Shanghai to become smoke-free. Pro- spective students and employees who smoke will not be recruited and tobacco products will not be on sale on campus. A random survey among 1380 students and teachers at Shanghai Medical University showed that smoking rates were $13 \%$ and $22 \%$, respectively. Two other medical schools in Shanghai, the Norman Bethune Medical School and Zhejiang Medical School, have also announced that they will no longer admit middle school graduates who smoke. - DS
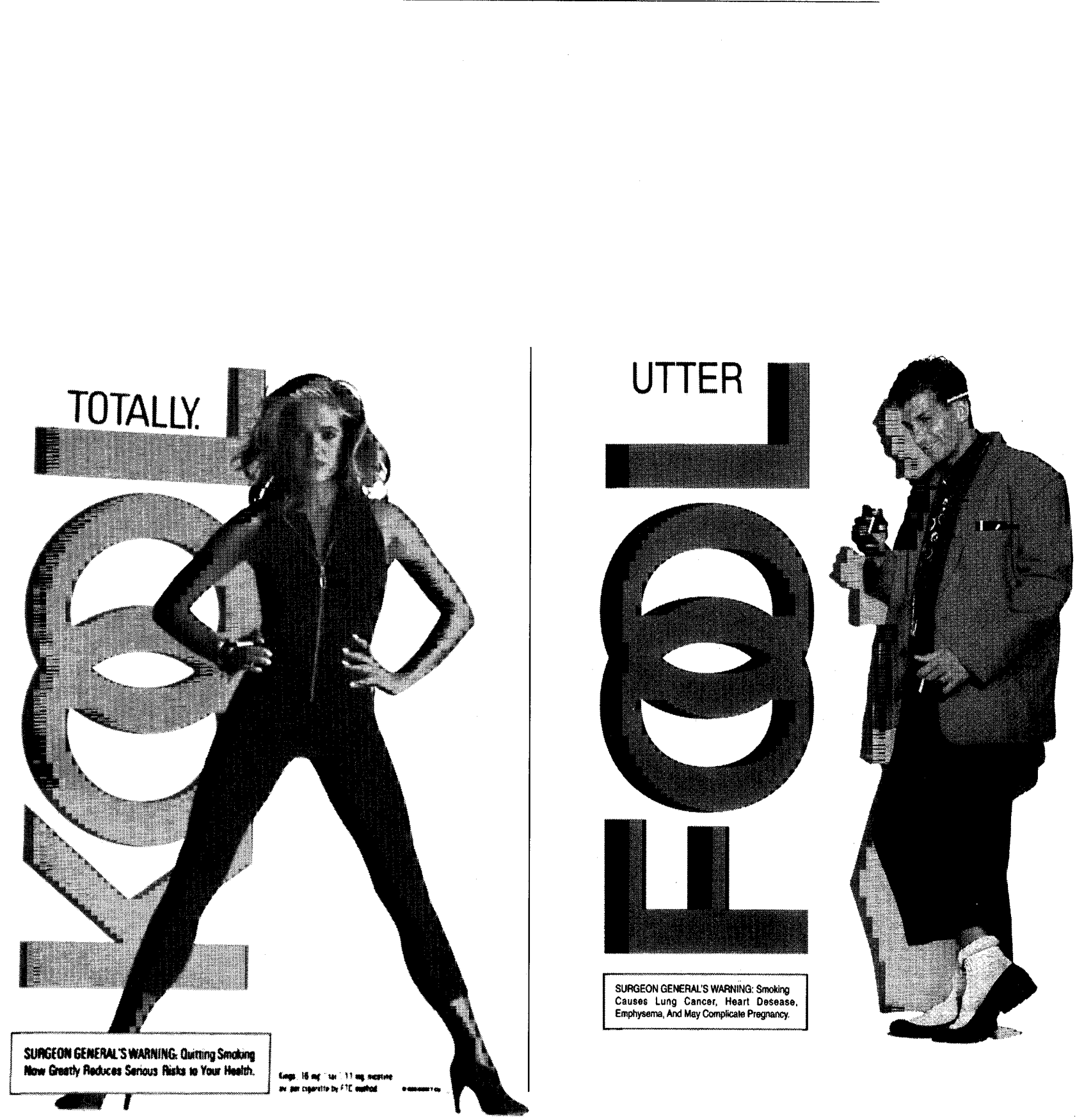

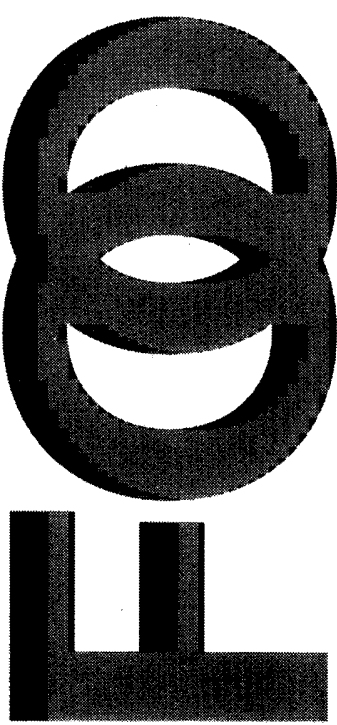

SURGEON GENERAL'S WARNING: Smoking Causes Lung Cancer, Heart Desease,

One of a series of postcards (right) distributed by Adbusters Media Foundation, a Canadian group comprising Adbusters magazine and Powershift Advertising Agency, together with one whose originators are probably not amused. The caption on the other side of the Adbusters card says: "When you see a cigarette ad in a magazine, write 'No Subscription Until You Stop Advertising Cigarettes' on their subscription card and mail it in. They'll get your message and pay the postage to boot." For more information, contact: Adbusters, 1230 West 7th Avenue, Vancouver, British Columbia, Canada V6H 1B7; tel: +1 604736 9401; fax: +1 604737 6021; e-mail: adbusters@adbusters.org; www home page: http://www.adbusters.org/adbusters/. 